\title{
Dossiê: Água, política e natureza
}

\section{Apresentação}

\author{
Wagner Costa Ribeiro
}

Cerca de 2 bilhões de pessoas não têm acesso à água de qualidade no mundo. No Brasil, 35 milhões de pessoas integram esse conjunto, o que é uma grande contradição, posto que o país detém cerca de 12 a 15\% do total de água doce do mundo. O caso brasileiro mostra que o acesso à água não depende da natureza, mas da política.

Por isso esse número 2 de AMBIENTES: Revista de Geografia e Ecologia Política, é mais que oportuno. É necessário aprofundar o debate sobre o acesso à água no Brasil, de modo a diminuir mais essa expressão da enorme desigualdade social que perdura no país.

Disputas pela água são frequentes no mundo e no Brasil. Na maior parte das situações elas ocorrem em área de escassez hídrica, mas também ocorrem quando a oferta da água é abundante. O uso da água é a causa principal a ser avaliada em casos de conflitos. Por isso a dimensão política prevalece, é preciso insistir.

Entre a comunidade de geógrafos observa-se um crescente interesse por diferentes aspectos que envolvem a água. Seus aspectos naturais, como a capacidade de emoldurar o relevo e transportar materiais, são temas recorrentes nas análises. Já os aspectos sociais ingressaram mais tarde, mas já se vislumbram grupos de pesquisa envolvidos com aspectos como águas transfronteiriças, impactos de barragens, conflitos pelo acesso à água em função de atividades produtivas intensivas no uso da água como as que envolvem o agronegócio, a mineração e a produção de energia. Os 
estudos que adotam a bacia hidrográfica como escala de análise buscam combinar aspectos naturais e sociais, mas nem sempre a dimensão política pode ser abarcada em uma escala natural, como será apontado em um dos artigos que compõe esse dossiê.

Nesse número é possível encontrar reflexões e análises que indicam premissas, teorias e conceitos para discutir os conflitos pela água e bem como a gestão por bacia hidrográfica. Também estão presentes análises que discutem como o uso da água pode contaminar áreas e rios, com implicações sociais de curto, médio e longo prazos, envolvendo diversos grupos sociais, como povos indígenas.

Espera-se que essas contribuições estimulem novas pesquisas sobre acesso à água que ajudem a implementar o Direito Humano à água, aprovado pela Assembleia Geral da ONU, em 2010, mas ainda longe de ser reconhecido e aplicado no Brasil. 